\title{
Félix Vicq d'Azyr (1746-1794): early founder of neuroanatomy and royal French physician
}

\author{
R. Shane Tubbs • Marios Loukas • \\ Mohammadali M. Shoja • Martin M. Mortazavi • \\ Aaron A. Cohen-Gadol
}

Published online: 29 March 2011

(C) Springer-Verlag 2011

\begin{abstract}
Although he lived a short life, Félix Vicq d'Azyr is considered as one of the greatest neuroanatomists of the eighteenth century although relatively little is written of his life and contributions. His descriptions of the brain were among the most accurate for his day with his Traité d'Anatomie et de Physiologie that epitomizes one of the finest neuroanatomical works. Vicq d'Azyr accomplished many other feasts during his life including being the first to use lithography in neuroanatomy, becoming a royal physician to Queen Marie Antoinette, and first describing multiple neuroanatomical structures including the central sulcus (almost 50 years prior to Rolando), insula, red nucleus, and substantia nigra. Eponymously, he is remembered for the mamillothalamic tract or bundle of Vicq D'Azyr. Furthermore, Vicq d'Azyr was an acquaintance of forefathers of the United States including John Adams. The present paper will review the life of Vicq d'Azyr and emphasize his contributions to our early understanding of neuroanatomy.
\end{abstract}

\section{Early life}

Vicq d'Azyr was a product of the Enlightenment. He was a physician, anatomist, historian, and social reformer (Fig. 1)

R. S. Tubbs $(\bowtie) \cdot$ M. M. Mortazavi

Pediatric Neurosurgery, Children's Hospital,

Birmingham, AL, USA

e-mail: Shane.Tubbs@chsys.org

\section{Loukas}

Department of Anatomical Sciences, St. George's University,

St. George's, Grenada

M. M. Shoja $\cdot$ A. A. Cohen-Gadol

Department of Neurosurgery, Clarian Neuroscience Institute, Indianapolis Neurosurgical Group and Indiana University, Indianapolis, IN, USA
[1-3]. He would become the French father of comparative anatomy and the originator of the theory of homology that attempted to link anatomical traits to a common ancestor. He was born on April 23, 1746 in Valognes (Normandy), the son of a Montpelier-trained physician, Maître Jean-Félix Vicq Sieur de Valemprey. His mother was Catherine Lechevalier who derived from nobility [3]. He studied philosophy at the seminary of Valognes and later, relocated to Caen. In Caen, he studied philosophy and met PierreSimon Laplace (1749-1792) who would go on to make a name for himself in physical chemistry [3]. In 1765, he enrolled in the University of Paris to study medicine. During his studies, influential teachers included the anatomist and surgeon Antoine Petit (1722-1794) and comparative anatomist Louis-Jean-Marie Daubenton (1716-1799). In 1772, Vicq d'Azyr defended his thesis on the protective effect of the cranium for the brain and passed his medical certification examinations [3]. Soon after graduating, he began teaching anatomy and in 1773 in Paris, he taught a popular course on morphology at the Jardin du Roi, currently the Museum of Natural History [2]. Soon, he fell ill to, presumably, tuberculosis and traveled back to Normandy to recuperate. During this time, Vicq d'Azyr began an in depth study of the anatomy and physiology of fish. He was admitted to the Académie des Sciences in 1774 with the support of his friend mathematician and political scientist Marie Jean Antoine Nicolas de Caritat or the marquis de Condorcet (1743-1794), and earned his doctorate the same year [2]. Early in his career, he determined that he would be a neuroanatomist and his treatises on this topic helped lay the foundation for this discipline.

In 1776, as the USA became a nation, Vicq d'Azyr continued his study of anatomy in Paris, following the recommendation of his teacher Petit. In fact, Petit had wished that Vicq d'Azyr would succeed him as chair of 


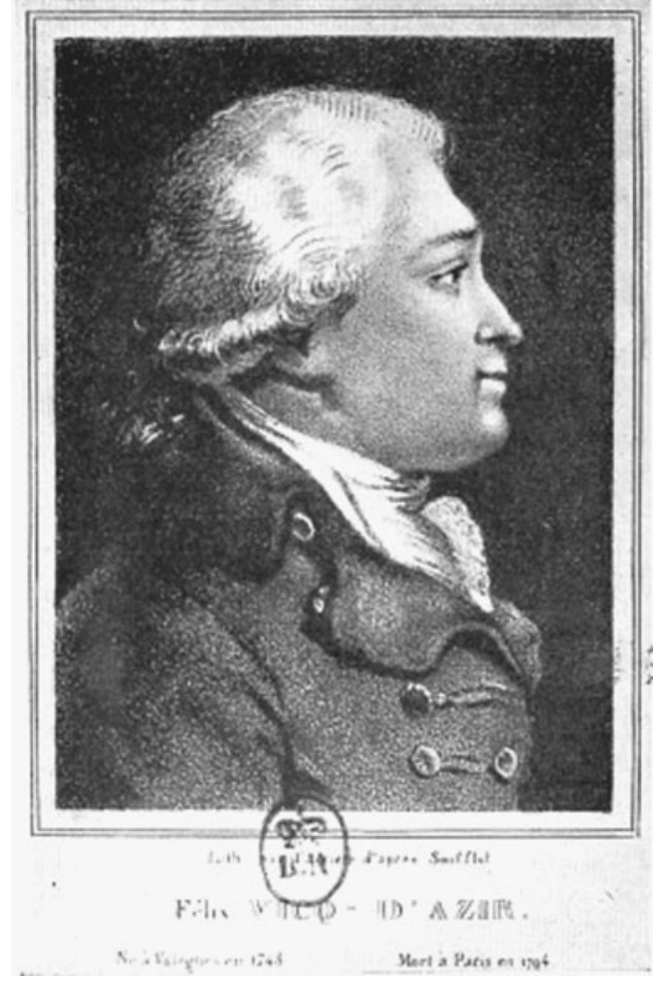

Fig. 1 Drawing of Félix Vicq d'Azyr (1746-1794) anatomy at the Jardin du Roi after his retirement in 1778, but the appointment went to Antoine Portal (1742-1832) who was supported by the Count of Buffon (1707-1788). One year after Petit's retirement, Vicq d'Azyr was married and over the next 2 years, lost his wife (the niece of Daubenton) and child both to tuberculosis. Of note, some sources state that he was childless [4]. In 1780, he became professor and chair of comparative anatomy at Alfort Veterinary School, a post he would hold for the next 8 years [3]. Vicq d'Azyr was instrumental in establishing the Société royale de médecine, and eventually, became the permanent secretary for this group. In 1788, he was elected into the Academie Francaise, the highest scientific honor in France. A year later, he succeeded Lassone as royal physician to Queen Marie Antoinette (1754-1793) [5]. Interestingly, he was in charge of the group that manufactured saltpeter used in gunpowder for the revolution [4].

\section{Neuroanatomical contributions}

During his 8 years in Alfort, he wrote with the aim of presenting a "grand tableau" or scheme of all species to illustrate a grand design of the animal kingdom, culminat-

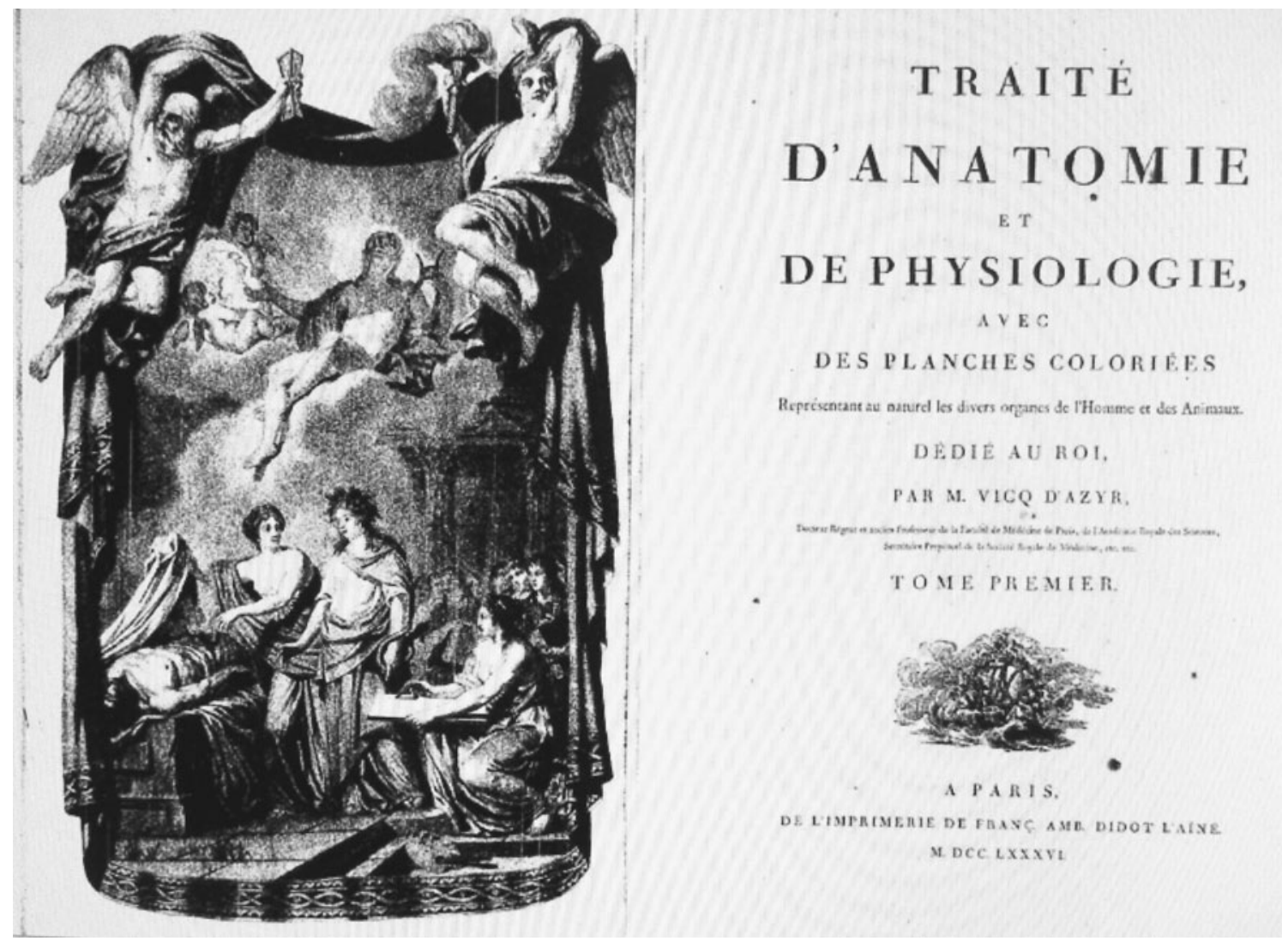

Fig. 2 Title page from Vicq d'Azyr's Traité d'anatomie et de physiologie-avec des planches colorës représentant au naturel les divers organes de 'Homme et des Animaux. F.A. Didot, Paris 
ing in man [5]. However, he was only able to write one volume of this work prior to his death. This five-part volume, dedicated to King Louis XVI, described the detailed anatomy of the brain (Fig. 2) [6], and represents some of the most accurate depictions of the brain of the eighteenth century [7]. In the introduction of this work, Vicq d'Azyr emphasized the importance of integrating form and function. The beautifully illustrated plates used in his tome were drawn by the noted Parisian engraver Alexandre Briceau, who is thanked by the author for his skills, stamina, and "endurance of foul odors" [6]. All plates were drawn from actual preserved human brains. One plate was a black and white taken from Soemmering's De basi encephali. Preceding each plate, Vicq d'Azyr provided detailed explanations that were followed by comments of earlier anatomists (e.g., Bidloo, Vieussens, Eustachius, Willis, Monro, von Haller) [2]. In his descriptions, Vicq d'Azyr often chided past anatomists, including Vesalius, for inaccuracies in their illustrations and descriptions.

For his studies of the brain, he was one of the first to use a chemical cocktail (alcohol, saltpeter, and hydrochloric acid) [8] for brain preservation, which would not become a standard method until the work of Reil (1759-1813) and horizontal (Fig. 3) and coronal sections of the brain for studying its anatomy. Vicq d'Azyr was the first to describe the substantia nigra although some have erroneously attributed this discovery to Samuel Thomas Soemmerring (1755-1830) [3]. In 1786, he described the mamillothalamic tract (bundle of Vicq d'Azyr) as "the white ribbon that rises from the mamillary eminence, forming a curve toward the anterior tubercle within the optic thalamus" [6]. He is credited with rediscovering the white line (line of Gennari) in the calcarine cortex and was the first to accurately show the convolutions of the cerebral hemispheres, which historically, had been considered little more than "sur un plat de macaronis" (macaroni on a dish) [8]. He divided the cerebral cortex into frontal, parietal, and occipital lobes. He described the deep gray nuclei including the basal ganglia, claustrum, and caudate nucleus and the foramen (cecum) of Vicq d'Azyr, which lies in the midline of the anterior pontomedullary junction and receives basilar artery perforators [3]. He also described the locus coeruleus and the centrum semiovale (Vicq d'Azyr's centrum), although the centrum was first portrayed by Vieussens. He gave the first detailed description of the course of the fornix and stria medullaris and of the anatomy of the hippocampus [3]. He named and identified the uncus, cuneus, and precuneus and was the first to describe the insula although eponymously, this structure carries the name of Reil [3, 8]. With air injection studies, he demonstrated the existence of the intraventricular foramen and noted that the superior sagittal sinus drained primarily into the right transverse sinus [3]. Vicq d'Azyr elaborated

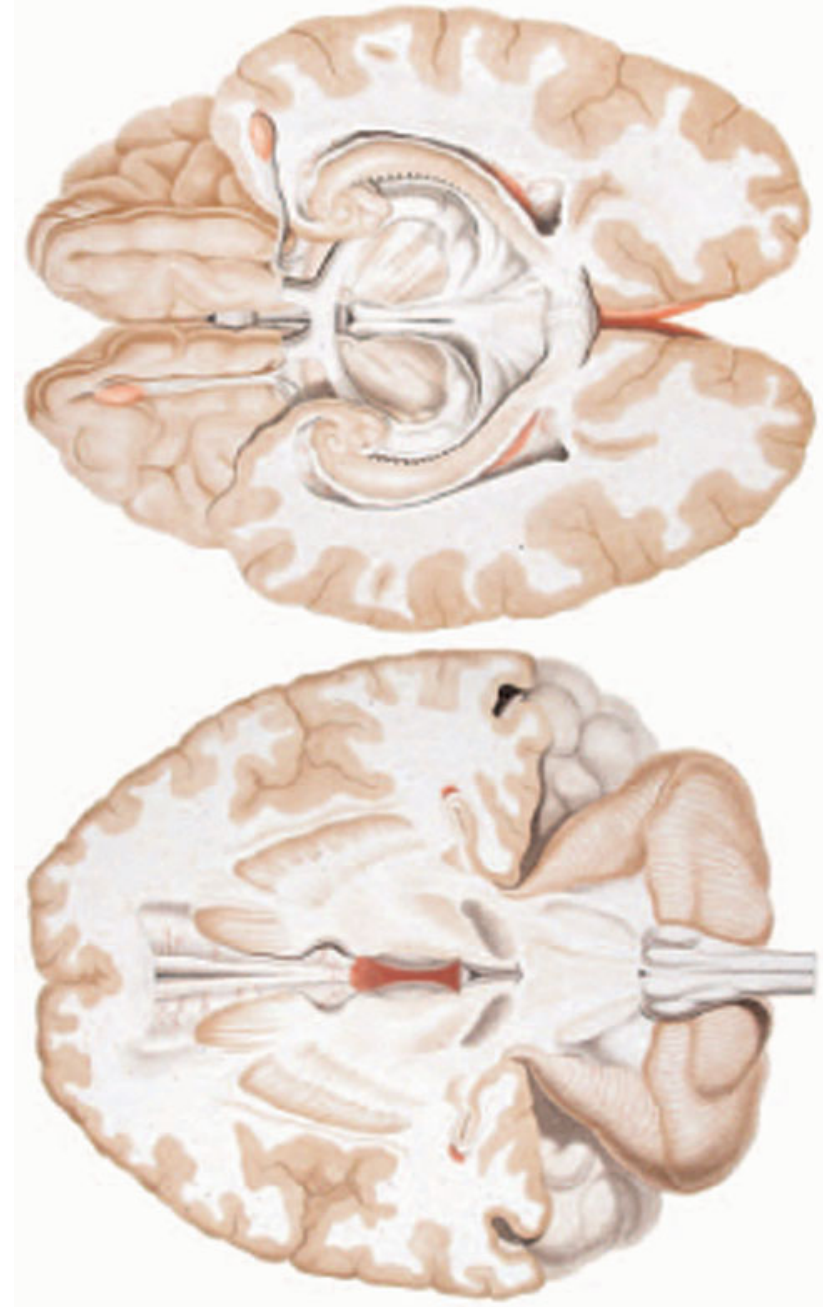

Fig. 3 Figure from Vicq d'Azyr's opus illustrating his method of horizontal sectioning the brain for study

on the arrangement of the fiber bundles of the spinal cord and their division into a posterior and two lateral columns with an anterior commissure.

Interestingly, it was Vicq d'Azyr and not the Italian anatomist Rolando who discovered the central sulcus and pre- and postcentral gyri. In fact, François Leuret (1796-1851) first applied the name Rolando to the central sulcus in 1839 (Anatomie Comparée du Systéme Nerveus) to direct attention toward Rolando's descriptions. When Leuret prepared his publication on the brain, he did not have access to the writings of Vicq d'Azyr [8]. Vicq d'Azyr first mentioned the central sulcus in 1796 in his Traité d'Anatomie et de Physiologie, which was one of the finest publications on the brain prior to the advent of microscopy.

The height of his career marked the beginning of the French Revolution. With this upheaval, he spent the last year of his life (1794) as military physician and superintendent of the anatomical collection that had belonged to 
the count of Orléans [8]. During this tumultuous time, he saw the King and Queen of France beheaded along with several of his friends and colleagues [4].

In 1790, he presented his plans for reformation of the method in which medicine was taught in France to the Constituent Assembly. He described the medical curriculum of his day as "partout viscieux et nul," perverted and worthless [3]. Vicq d'Azyr's outline called for grouping together schools of medicine, surgery, veterinary, and pharmacy with close union to hospitals and additionally, for the active participation of medical students in clinical work and competitive examinations. Such vision resulted in the creation of three Écoles de Santé (Schools of Health) being established in Paris [10, 11].

\section{Connections to American forefathers}

In 1783, Vicq d'Azyr corresponded with the second president of the USA, John Adams (1735-1826), regarding collaborative efforts between scientific organizations in the USA and France [9]. Later in 1789, he became friends with American statesman and founding father of the United States Gouverneur Morris (1752-1816) during his function as United States minister to France. Parent [3] stated that it is believed that Morris may have transmitted letters from the King and Queen of France to London with the aid of Vicq d'Azyr. During Benjamin Franklin's trips to France, he met and also became friends with Vicq d'Azyr [5]. The two discussed various issues. For example, letters of correspondence show that these men were intrigued by the potential of infectious agents being transferred from the dead to the living $[12,13]$. Franklin brought to Vicq d'Azyr's attention the case of illness in archaeologist that resulted, presumably, from contact with ancient Egyptian mummies. In fact, he would deliver Franklin's official eulogy to the Academy of Sciences on
March 1791. He began this speech by "A man is dead, and two worlds are in mourning" [3].

Vicq d'Azyr died from uncertain causes (perhaps tuberculosis) on June 20, 1794 during The Reign of Terror (la Terreur, 1793-1794) [14]. His short life was filled with discoveries and descriptions that continue to propel our understanding of the human nervous system.

\section{References}

1. Hannaway C (1994) Vicq d'Azyr, anatomy and a vision of medicine. Clin Med 25:280-290

2. Mandressi R (2005) Félix Vicq d'Azyr: l'anatomie, l'État, la médecine. http://www.bium.univ-paris5.fr/histmed/medica/vicq.htm.

3. Parent A (2007) Felix Vicq d'Azyr: anatomy, medicine and revolution. Can J Neurol Sci 34:30-37

4. Goldblatt D (1986) The key to the brain Felix Vicq d'Azyr (1748-1794). Sem Neurol 6:231-237

5. Spillman R, Felix Vicq D’Azyr and Benjamin Franklin (1941) J Nerv Mental Dis 94:428-444

6. Vicq d'Azyr F (1786) Traité d'anatomie et de physiologie — avec des planches colorës représentant au naturel les divers organes de 'Homme et des Animaux. F.A. Didot, Paris

7. Goodrich T (2000) A millennium review of skull base surgery. Childs Nerv Syst

8. Farrell PS, McHenry LC (1987) Fragments of neurologic history: Felix Vicq d'Azyr and neuroanatomy. Neurology 37:1349-1350

9. Adams CF (1853) The works of John Adams, second President of the United States. Vol VIII. Little, Brown and Company, Boston

10. Mandressi R (2008) The past, education and science. Félix Vicq d'Azyr and the history of medicine in the18th century. Med Secoli 20:183-212

11. Clarac F, Boller F (2010) History of neurology in France in History of Neurology. In: Aminoff MJ, Boller F, Swaab DF (eds) History of neurology. Elsevier, Edinburgh, pp 629-656

12. Sparks J (1838) The works of Benjamin Franklin, vol. VI. Hilliard, Gray, and Company, Boston

13. Peumery JJ (2001) Vicq d'Azyr et la Revolution Francaise. Hist Sci Méd 35:263-270

14. Sournia JC (1994) Felix Vicq d'Azyr, founder of the Academy of Medicine (1748-1794). Bull Acad Natl Méd 178:1237-1243, discussion $1243-1244$ 